AUTHOR:

Prof E.K. Niemczyk ${ }^{1}$

Dr Z.L. de Beer ${ }^{1}$

Prof H.J. Steyn ${ }^{1}$

AFFILIATION:

${ }^{1}$ North West University,

South Africa

DOI: http://dx.doi.

org/10.18820/2519593X/pie.v39.

i1.11

e-ISSN 2519-593X

Perspectives in Education

2021 39(1): 173-188

PUBLISHED:

12 March 2021

RECEIVED:

10 November 2020

ACCEPTED:

2 February 2021

\section{THE CHALLENGES POSED \\ BY COVID-19 TO THE BRICS \\ EDUCATION SYSTEMS: \\ LESSONS TO BE LEARNT}

\begin{abstract}
It is considered an axiom that the national education system is expected to render a service during the real and ever-changing educational needs of a given nation. Typically, the primary functioning is characterised by the provisioning of an educationally determined pathway for each student according to their specific contexts. A real state of emergency arises when the national community is suddenly faced with dramatic challenges such as those posed by the external factors namely the global outbreak of COVID-19. In this situation, the unique challenge for individual national education systems was to address the educational needs of the students and the community with the pre-condition to safeguard their health in the face of the pandemic. The response of each education system had to prioritise the implementation of health protocols to safeguard all education stakeholders, along with the provision of quality education. The objective of this article was to explore the approaches and practices that the BRICS nations (Brazil, Russia, India, China and South Africa) implemented during the time of the pandemic. To accomplish this objective, a systematic document analysis was conducted that ultimately allowed the identification of lessons to be learnt. The results show many similar approaches employed by the BRICS such as transitioning to online teaching, devoting funds to address emerging challenges and developing new teaching strategies. The article concludes with the lessons learnt from the nations under investigation.
\end{abstract}

Keywords: BRICS member states; national education systems; external contextual forces; education responses to COVID-19; education system planning.

\section{INTRODUCTION}

COVID-19 has brought a great adversity to global society including hardships for the educational sector. With the state of emergency, the national communities were faced with dramatic challenges that they had to tackle in a timely manner (OECD, 2020). The unexpected global pandemic posed a serious threat, not only to human health, but also to the social, cultural, political and economic aspects of life. The pandemic especially affected vulnerable population including people living in poverty, refugees, older individuals and individuals with disabilities. It is also important to 
acknowledge the existence of disparities between developed and developing nations, which cope with the challenges based on their social and economic situation (UNDP, 2020). To that end, nations around the world took different measures to contain the spread of the pandemic within their national borders. Many nations enforced lockdown, social distancing, bans on mass gatherings and international travel, the closure of entertainment venues, and only allowed the sale of essential products. Along with the developments related to the COVID-19 pandemic, measures taken by these nations are being reviewed and adjusted on an ongoing basis (UNICEF, 2020). As reported by the UN (2020a), the pandemic exposed challenges, vulnerabilities and inequities, along with human resourcefulness in many areas of life, including in the education sector. In a short time, COVID-19 has changed the ways in which students are educated around the world and has forced the education sector to adapt to the state of crisis rapidly.

Internationally, the education sector experienced a massive disruption due to the COVID-19 pandemic (UNESCO, 2020a). As stated by the Director-General of UNESCO, Audrey Azoulay, it is only through collaboration and innovative action that students and teachers can be supported in these unexpected times of crises. This message brought attention to the importance of inclusion and equity as well as the necessity to prompt the sharing of experiences to unlock solutions. In support of the statement of the Director-General of UNESCO, the goal of this article is to share the approaches and practices that the BRICS nations implemented in education during the challenging times of the pandemic. Thus, the goal of this article, in alignment with the research question, was to discover the approaches undertaken by BRICS nations to confront COVID-19. To accomplish the objective of this article, a comparative qualitative study was conducted based on the document analysis method. As articulated by Khakpour (2012), comparativists often study a particular topic or phenomenon in two or more countries. In this case, a comparison was made across the five BRICS member states in order to identify the approaches that each nation had implemented at all levels of education to confront COVID-19. Data collection involved purposeful sampling through which publicly available and relevant documents were selected. The documents included government reports, reports of international organisations, policy briefs, journal articles, chapters in books and e-news reports. Bowen (2009) describes a document analysis as a methodical process that entails reviewing, examining and evaluating documents to gain understanding and meaning. To that end, the conclusion of this article provides meaning in a form of lessons learnt, which may lead to awareness and actions that advance effective education practices in response to COVID-19, especially if the pandemic will protract. As mentioned earlier, sharing knowledge and experiences provides a way to unlock solutions and, therefore, inform future practice in education.

\section{THEORETICAL UNDERPINNINGS}

\subsection{The challenges of COVID-19}

As reported in scholarly literature, the coronavirus, officially named the COVID-19 virus on 11 February 2020 (WHO, 2020a) caused havoc around the world and in 10 months became one of the most discussed global topics. After its first notation on the timeline of the World Health Organization (WHO) on 31 December 2019, on 10 October 2020, the spread was reported as 37824151 COVID-19 cases, of which 28386548 patients recovered and 1082405 passed away (Worldometers, 2020). The WHO categorised the COVID-19 outbreak as a pandemic on 11 March 2020 (WHO, 2020b). In order to curb the spread of COVID-19, the organisation 
advised that infections should be limited and could be decreased by using one of five reaction levels. In general, the WHO promoted the following basic measures to be adhered to, namely to wash hands thoroughly, wear a face mask, keep a safe distance from other people, stay at home as much as possible and to avoid large gatherings of people (WHO, 2020c).

All the above-mentioned measures had a direct influence on the provisioning of education in all educational institutions. On 26 March 2020, the WHO (2020a) and the United Nations Educational, Scientific and Cultural Organization (UNESCO) officially emphasised the need to ensure quality education for all students who experienced a period of unprecedented educational disruption. A document named Key Messages and Actions for COVID-19 Prevention and Control in Schools was published providing the provisioning of basic principles to effectively manage the effects of COVID-19 in education. Educational institutions were advised to update their emergency plans and to cancel all mass meetings to implement general safety measures and to consider special measures such as staggering school times. School policies had to be adapted and plans had to be developed for the continuation of quality education, such as online teaching strategies, assigning home projects for studying purposes and implementing educational radio and television broadcasts. A checklist about the relevant actions to manage COVID-19 was provided for the use of education managers, teachers and parents (WHO, 2020d: 4-12). UNESCO also put together a comprehensive coalition of education interest groups to unlock creative solutions in order to support all groups of students and educators during and after the impact of COVID-19. Distance education was excepted as the most achievable way forward. In addition, the coalition collaborated with education ministers and departments on an international level to realise the advantages of distance education according to the different unique contexts (UNESCO, 2020b).

Overall, it is clear that COVID-19 had a dramatic effect on all the countries and societies across the world. Individual governments and education departments across the world reacted to the challenges of COVID-19, often according to the advice of international organisations and practices employed in other countries. The impact was also evident in all the elements of education systems, especially for updating policies, provisioning of the required additional funding to support the required changes and developing new programmes and teaching strategies.

\subsection{COVID-19 as an external contextual factor of the national education system}

The influence of COVID-19 on the provisioning of individual education systems across the world represents a classical manifestation that the context of, or incidents in the target group, have an explicit and implicit effect on the nature and functioning of a given national education system (Steyn, Wolhuter, Vos \& De Beer, 2017).

COVID-19, as an occurrence in national society, can be classified as an external contextual factor of a particular national education system. As evident in scholarly literature, two types of contextual factors that influence an education system can be identified, namely internal and external contextual factors (Steyn \& Wolhuter \& De Beer, 2017). COVID-19 can be classified as an external contextual factor because its presence in the national community necessitates the reactions of that education system to those challenges. More precisely, COVID-19 can be classified under the category of socio-economic contextual factors because it negatively influences the physical and mental health of national society and the detrimental effects on 
the local and national economies. The relation of the external and internal contextual factors to a national education system is represented in Figure 1.1 (Steyn \& Wolhuter, 2014: 151).

\begin{tabular}{|c|c|c|c|}
\hline & \multicolumn{3}{|c|}{ Educational system } \\
\hline Contextual external tendencles & \multicolumn{3}{|c|}{ Contextual internal tendencies } \\
\hline Demography & \multirow{7}{*}{ 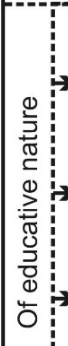 } & \multirow{6}{*}{$\begin{array}{l}\text { - Education system } \\
\text { policy } \\
\text { - Education system } \\
\text { administration } \\
\text { - Structure of } \\
\text { teaching } \\
\text { - Support services }\end{array}$} & \multirow{7}{*}{ 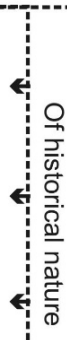 } \\
\hline Climate and geography & & & \\
\hline Physical and psychological characteristics & & & \\
\hline Science and technology & & & \\
\hline Language & & & \\
\hline Sosio-economical tendencies & & & \\
\hline Political/Institutional tendencies & & & \\
\hline Philosophical tendencies & \multirow{2}{*}{\multicolumn{3}{|c|}{ 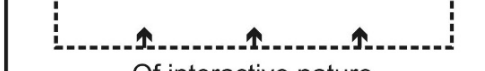 }} \\
\hline Co-operaters/competitors & & & \\
\hline
\end{tabular}

Figure 1.1: The external and internal contextual factors of a national education system

The fact that governmental institutions lead the way in the reaction of the education system to the national crisis of COVID-19 can be found in the understanding of the relationship between the target group and the national education system, namely that the state acts as the coordinator of the participation of the many interest groups (Steyn \& Wolhuter, 2014: 115-118).

In conclusion, it is clear that the theory that the structure and functioning of the education system is affected by an external contextual factor such as COVID-19 is valid. What is important to notice is that a single incident of crisis can influence the structure and functioning of a particular education system.

\section{COMPARING THE IMPACT OF COVID-19 ON THE EDUCATION SYSTEMS IN BRICS}

The comparison of approaches that BRICS nations implemented due to the external contextual factor, namely COVID-19, that influenced all the education systems has potential (a) to maximise an understanding of a national education system and (b) to provide lessons that may inform future reactions of education systems in comparable situations. Comparing the responses of the education systems of the BRICS countries is particularly useful because of the following (De Beer, 2017: 69):

- the fact that education plays an important role in the development of each of the countries;

- the fact that it is agreed by the BRICS countries to synchronise the functioning of their education systems; and

- the sheer size of the BRICS organisation: $26 \%$ of the world's surface, $42 \%$ of the total world population and $27 \%$ of the gross domestic product of the world and each with a significant regional influence. 


\subsection{The impact of COVID-19 on the Brazilian education system}

\subsubsection{The situation of COVID-19 in Brazil}

As reported by Worldometer (2020c) website providing reliable real-time statistics, the current population of Brazil accounts for 212962 134, which is equivalent to $2,73 \%$ of the world population. On 26 February 2020, the government of Brazil confirmed the first case of the coronavirus and from that moment on, the numbers increased from 13 cases of infected individuals in early March to 5000000 cases reported in early October 2020. In terms of deaths due to the pandemic, the numbers increased from 77 cases in late March 2020 to almost 148000 cases at the beginning of October 2020. On a global scale, in October 2020, Brazil was listed in third place as one of the most at-risk countries.

Similar to other nations, Brazil adopted various measures to slow down the spread of the virus. The World Bank (2020a) reported that the country was slowly recovering from the $2015 / 2016$ recession and, therefore, its economic state was frail even before the outbreak of COVID-19. Focusing specifically on education, Brazil faced many challenges due to an already-existing lack of financial resources, resulting in cuts to their education budget, as well as severe inequalities among education provisioning based on geographic location, social status and access to education.

\subsubsection{Responses from the Brazilian education system}

The Brazilian school year aligns with the calendar year where classes start in February and end in December. The closure of schools in March 2020 created an enormous concern about how to deal with the entire school year. As reported by Berti (2020), it was heavily debated whether students should repeat their current grades in 2021 or if the material covered in 2020 should be delivered along with the material offered in 2021. Ultimately, the Ministry of Education (2020a) took several measures in this regard. In terms of immediate changes to teaching strategies, face-to-face teaching had to be replaced with distance teaching and education at home. In fact, not all schools were prepared to teach remotely and not all parents were prepared to home-school their children. It is important to note that parents' ability to assist children with schoolwork has a strong correlation with their socio-economic status. Some of the well-equipped Brazilian states assisted parents by providing broadcasted educational content on open television via satellite, along with social media livestreaming and applications (World Bank, 2020). Unequal access to computers, digital tools and internet connectivity presents a basic problem for schools and teachers to engage students from lowincome families in remote education (Parreiras \& Macedo, 2020).

Primary schools and higher education institutions were allowed to distribute the workload in a period different from the 200 school days provided for by law. Many higher education programmes extended their registration dates. Face-to-face defences of Master's dissertations and doctoral theses were suspended. Furthermore, the Ministry of Education provided university students with the opportunity to convert their studies to internships, for example, where students of Medicine and Nursing, Pharmacy and Physiotherapy were able to work in medical clinics and emergency care units during the emergency period of the coronavirus pandemic (Ministry of Education, 2020).

Based on the information provided by the Brazilian Ministry of Education (2020a) and the World Bank (2020a), the following is a concise list of support services designed during the early stage of the pandemic to deal with education vulnerabilities. It is important to mention 
that the Brazilian Ministry of Education is a major stakeholder and educational policymaker responsible for quality education.

- Distributing school lunches: In order to prevent possible malnutrition, the government authorised the distribution of food baskets to disadvantaged families.

- Supporting parents in home-schooling: Keeping parents involved in children's education during the COVID-19 pandemic became a priority by ensuring a broad use of platforms to provide distance teaching (digital, television, radio) in order to reach families with no connectivity.

- Improving connection: Local governments engaged with local Internet providers to reduce connection costs in an effort to make it more affordable for vulnerable families and by sending regular text messages or providing phone lines for communication between parents and teachers.

- Providing help centres for teachers to ask questions, receive feedback and search for emotional support.

- More technology for schools and universities: More than 123000 students and teachers were provided with technological resources.

\subsection{Impact of COVID-19 on the Russian education system}

\subsubsection{The situation of COVID-19 in Russia}

It was reported by Worldometer (2020c) that the population of the Russian Federation amounts to 145951 318. Furthermore, the same source confirmed that the first coronavirus case was confirmed in Moscow on 27 February 2020, which, by the end of September 2020, quickly grew to 1200000 cases. The number of deaths due to the pandemic also increased, however, at a significantly less alarming rate. By the end of March 2020, only four deaths were reported, while 21500 deaths were reported at the beginning of October 2020. In terms of the global picture, Russia is after Brazil and is listed as the fourth nation most at risk.

Foy and Seddon (2020) reported that Russia, similar to other nations, adopted emergency measures such as quarantines, border closures, visa restrictions, restrictions on large public events and the cancellation of most flights and rail links with China. Meanwhile, education institutions adapted new teaching practices and strategies. By the end of March 2020, schools and higher education institutions rapidly moved to online teaching, learning evaluation processes were accordingly reorganised, and remote support was established for students and educators. President Putin delegated educational decisions to 85 regional governors of the Russian Federation.

\subsubsection{Responses from the Russian education system}

The Ministry of Education (2020) recommended that the regional authorities organise educational institutions in such a way that children and teachers engage in educational activities from home. As per the Ministry of Education recommendation, some kindergartens closed completely, while other special groups with a small number of children remained open. All three levels of general schooling, more specifically 16,5 million school children in more than 9000 schools shifted to online learning in all regions. Class schedules were adjusted in accordance with the curriculum for each subject and the lesson time was reduced to 30 minutes. The organisation of distance learning included arranging training sessions, consultations, webinars on the school portal and platforms using electronic educational 
resources. Furthermore, the Ministry of Education decided that the entry exams to universities would be taken in 2020 and only by those graduates who would enter higher education in 2020. It was decided that students who did not plan to enrol for higher education could be awarded grades at the end of the year.

The World Bank report (2020) indicated that in March 2020, 248 universities reporting to the Federal Ministry shifted to distance education. In order for universities to prepare for online formats, an extra week of vacation was granted to students from 28 March 2020 to 5 April 2020. State accreditation was prolonged for one year for those universities whose accreditation expired between March 2020 and December 2020.

On 1 September 2020, Russian schools resumed face-to-face classes for the new school year, which does not align with the calendar year and begins in September. As reported by The Moscow Times (2020), in preparation for the reopening of schools, Moscow city authorities ran coronavirus tests on all employees of the capital's education fraternity. Those who tested positive were temporarily kept away from schools. In terms of higher education, universities had the right to shift the beginning of the school year by two months. A total of 25 universities opted for delaying opening day and planned to introduce mixed teaching strategies to prevent the new coronavirus infection from spreading

The World Bank (2020) reported that the Ministry of Education had launched a hotline to support regional ministries, schools and colleges in organising distance learning. Based on several documents released by the Ministry of Education (2020d), many initiatives received financial support from the ministry during the pandemic. For instance, the following support services were provided by the Russian Ministry of Education (2020d) to facilitate students' online learning:

- A free public platform containing clear and proven educational material for self-learning at home for students in Grades 1-11. Educational material for students from Grades 9-11 were designed for basic and in-depth levels, including preparation for compulsory examinations. The necessary resources could be stored on computers, tablets and phones.

- The Ministry of Education, in partnership with public television, provided the implementation of an educational television project for high school students in preparation for examinations. The key video lessons from the country's leading teachers were broadcasted.

- A special resource centre was opened in the area of recreation and health for children.

- A navigator of consultation centres was launched on a single free State portal to support parents. A total of 163 counselling centres provided psychological, pedagogical and methodological support for the upbringing and education of children as well as distance learning.

- Information for specialists and parents, which was important for the education of children with special educational needs, was loaded onto a designated website. The site contained methodological and informational material for teachers, defectologists and psychologists. Parents could also consult with leading specialists in the field of remedial education and psychology.

- The Ministry of Education recommended that the regional authorities provide school meals for socially disadvantaged students from low-income families. 
- Provision was made for the organisation of temporary employment for graduates in educational institutions under the supervision of such organisations and the continuation of vocational training.

\subsection{The impact of COVID-19 on the Indian education system}

\subsubsection{The situation of COVID-19 in India}

The following statistical synopsis illustrates the effect of the COVID-19 pandemic on India. India's current population stands at 1383085891 people (United Nations, 2020b), which is equivalent to $17,7 \%$ of the world population (United Nations, 2020b). The Government of India confirmed India's first case of the coronavirus disease on 30 January 2020 (Ward, 2020). The infection rate in India grew exponentially. If India's infection rate is compared to the rest of the world, India has the second-highest infections after the United States of America on 30 September 2020 (Worldometer, 2020a). The Worldometer (2020a) further informed that as of 30 September 2020, India had 6229474 infections. Focusing on India's statistics regarding the number of cases, fatalities and recovery rates, the outcomes are as follows: A total of 97 541 people died from the virus on 30 September 2020, 5187825 made a full recovery and 944 048 active cases remained. India's recovery rate stands at $84,84 \%$ as of the end of September 2020. One of the most important statistics that could influence the COVID-19 infection number is the "test per million" rates. India has tested 53000 per 1000000 inhabitants.

Prime Minister Narendra Modi ordered a nationwide lockdown as a preventive measure to flatten the curve of the COVID-19 infection for 21 days on 24 March 2020 (Government of India, 2020b). Lockdown phase 1 limited the movement of 1,38 billion people living in India (Gettleman \& Schultz, 2020). Nearly all factories and services as well educational institutions, were closed (Government of India, 2020b). As reported by the Government of India (2020b), on 14 April 2020, the nationwide lockdown (Phase 2 from 15 April 2020 to 3 May 2020) was extended to 3 May 2020. Every town and state had to be evaluated to see if the spread of COVID-19 had been contained. Lockdown areas were classified as green zones with no infections, orange zones indicated some infection and red zones indicated the presence of high infection. Relaxation on industries included agricultural businesses, public works programmes, cargo transportation and banks and government centres distributing benefits would open as well (Government of India, 2020b). Small retail shops were also allowed to open with half of their staff. On 1 May 2020 (Phase 3 from 4 to 7 May 2020), the Government of India further extended the lockdown period to two weeks beyond 4 May 2020. Some relaxations were allowed except for hotels, cinemas, schools, colleges, restaurants, shopping centres and sports complexes remained closed, as indicated during the first phase. The Government of India (2020b) decided that the religious, political, social and cultural gatherings were also still not allowed (Government of India, 2020b). On 17 May 2020, the Ministry of Home Affairs extended the lockdown for another two weeks with additional relaxations.

\subsubsection{Responses to COVID-19 by the Indian education system}

In response to the COVID-19 pandemic, the Indian Government closed all its educational institutions under Lockdown 1. This closure affected 1,5 million schools, 8,5 million teachers and 250 million children (UNICEF, 2020). The lockdown led to the suspension of all classes and examinations at schools and universities. As a result, students' academic year was disrupted. The contact method of teaching and learning was not possible, which led to a new era of online teaching (UNICEF, 2020). 
Kumar (2020) states that Indian teachers and students were confused during the onset of the COVID-19 pandemic, but later realised that the lockdown forced them to adapt and taught them ways to manage during the emergence of new epidemics. Pravat (2020) accentuates the fact that COVID-19 has created many challenges and opportunities for the educational institutions to strengthen their technological knowledge and infrastructure. This implied the necessity for computers with Internet access and software that could enable online teaching. Software such as Microsoft Teams, Vidyo, Google Meets and WhatsApp became very important to relay educational content and to facilitate learning and teaching. The new normal of online teaching drew attention to the digital divide in India (Pravat, 2020).

As reported by the Ministry of Human Resources Development (MHRD, 2020), the Indian government took specific measures to overcome the digital divide and other pandemic driven challenges. It is important to mention that the Ministry of Education in India provided additional financial resources for support services. The first measure was that teaching had to be done online. School education was supported by the MHRD with the following initiatives (MHRD, 2020):

- Diksha made more than 80000 e-Books available for grades 1 to 12.

- e-PATHSHALA: In this web portal, the National Council of Educational Research and Training (NCERT) deployed 1886 audios, 2000 videos, 696 e-Books and 504 flip books in different regional languages for grades 1 to 12 .

- National Repository of Open Educational Resources (NROER): The NROER portal has a total of 14527 files, including 401 collections, 2779 documents, 1345 interactive, 1664 audios, 2586 images and 6153 videos in different languages.

Higher Education support consisted of (MHRD, 2020) the following:

- SWAYAM: The national online education platform hosts 1900 courses covering school (grades 9 to 12) and higher education (undergraduate, postgraduate programmes) in all subjects, including Engineering, Humanities and Social Sciences, Law and Management courses.

- SWAYAM PRABHA: This platform has $32 \mathrm{DTH}$ television channels transmitting educational content daily. The channels cover school education (grades 9 to 12) and higher education (undergraduate, postgraduate, Engineering out-of-school children, vocational courses and teacher training) in Arts, Science, Commerce, Performing Arts, Social Sciences and Humanities subjects, Engineering, Technology, Law, Medicine and Agriculture.

The MHRD also made access to these facilities and platforms free of charge. Students in India, therefore, had access to a wide variety of online educational sources at no cost to students.

\subsection{Impact of COVID-19 on the Chinese education system}

\subsubsection{The situation of COVID-19 in China}

The population of the People's Republic of China in October 2020 was 1440722 001, which equates to $18,47 \%$ of the world population (UN, 2020). China was the first country to report the COVID-19 virus and it also alleges to be the country from which the virus is derived. The initial outbreak of COVID-19 was in Wuhan, China (Fox, 2020). China had 85414 confirmed cases on 30 September 2020. A total of 80594 of these persons have recovered from the virus and 4634 persons have succumbed to COVID-19. On the $30^{\text {th }}$ of September China had 
186 active cases, of which $184(99 \%)$ are mild and $2(1 \%)$ persons are in critical condition (Worldometer, 2020b). The People's Republic of China already conducted 160 million tests at the end of September 2020.

The Chinese Action Plan to contain the virus focused on Wuhan in the Hubei province. The lockdown of Wuhan was promulgated on 23 January 2020 and 11 million people were quarantined (Reuters, 2020). Soon after the Wuhan lockdown, travel restrictions were also imposed on the nearby cities of Huanggang and Ezhou. Later, restrictions were also imposed on the remaining 15 cities in the Hubei province, restricting the movement of nearly 57 million Chinese citizens (CNN, 2020). Wenzhou, Zhejiang, implemented a seven-day lockdown on 2 February 2020, which allowed one person per household to go out once every two days for food and medicine only (Straitstimes, 2020). The lockdown of Wuhan officially ended on 8 April 2020. The People's Republic of China acted fast in their response to the pandemic and was the first country with a partial stringent lockdown. China contained the COVID-19 outbreak with a very low population to infection ratio of $85414: 1440722001$, which equates to one infection per 59284 persons (Straitstimes, 2020).

\subsubsection{Responses to COVID-19 by the Chinese education system}

The People's Republic of China was the first country to close schools selectively on 16 February 2020 with other countries that followed suit. Chinese education institutions were closed for more than 18 weeks, which affected nearly 200 million primary and secondary school children (OECD, 2020; UNESCO, 2020c). Wyman (2020) conveyed the main challenges that the Chinese education system faced. The first challenge reported was the poor quality of a number of online programmes and the second one was the low quality of some teaching applications and the need to cancel the major examinations.

The action plan of the Ministry of Education of the People's Republic of China started with an initiative titled Ensuring learning is undisrupted when classes are disrupted (MoE, 2020). The Minister of Education and the Minister of Industry and Information Technology joined forces to enable online learning and teaching with the following initiatives, namely to (UNESCO, 2020) -

- mobilise all major telecom service providers to increase the Internet connectivity service for online education, especially for the underserved regions;

- upgrade the bandwidth of major online education service platforms, especially the capacity of the National Cloud-Platform for Educational Resources and Public Service in serving millions of visitors simultaneously;

- mobilise society-wide resources for the provision of online courses and resources. More than 24000 online courses were made accessible for university students. A total of 22 validated online course platforms, most of them empowered by Artificial Intelligence, were mobilised to provide primary and secondary schools with free online courses;

- adopt flexible and appropriate methodologies to facilitate learning. Schools and teachers were advised to choose appropriate modes of delivery based on local e-readiness, including online platforms, digitalised televisions or mobile applications. Teachers received guidance on teaching methodologies, including through the livestreaming of online tutorials and Massive Open Online Courses (MOOCs). The recommended number of online learning hours varied by grade to - 
- strengthen online security through collaboration with the telecom sector and online platform service providers;

- provide psychosocial support and courses to impart knowledge about the virus and protection against it; and

- provide substantial financial support to maintain quality education.

The efforts of the People's Republic of China to make teaching and learning available on this enormous scale are notable and may be used as a framework for future crises.

\subsection{The impact of COVID-19 on the South African education system}

\subsubsection{The situation of COVID-19 in South Africa}

South Africa had tested 4229709 citizens out of a total population of 59308690 by 3 October 2020. That represented a ratio of tests per total population of $0.0711: 1$. As of the 3 of October 2020 a total of 677833 South Africans has tested positive, of which 611044 have recovered and 16909 people have passed away (SAcoronavirus, 2020).

The South African initial lockdown of Alert Level 5 was announced on 26 March 2020 and lasted until 30 April 2020 (RSA, 2020a), followed by Alert Level 4 ( 1 to 31 May 2020), Alert Level 3 ( 1 June to 17 August 2020), Alert Level 2 (18 August 2020) and Alert Level 1 on 21 September 2020 (RSA, 2020a). The primary aims of the alert levels were to contain the virus by limiting the movement of people, instituting several health measures and by limiting the gathering of people on various levels. All of these had a major impact on the provision of education and educational institutions. Alert Level 1 represented a situation where most of the normal societal and economic activities could resume.

\subsubsection{The response to COVID-19 by the South African education system}

The South African Government closed all Basic and Higher Education institutions from 18 March 2020. It partially opened the educational institutions on Alert Level 3. The number of students was restricted according to the physical spaces available for teaching and other activities such as breaks between classes. The students' temperatures had to be measured and personal protective gear had to be worn. Educational institutions physically closed for nearly three months. These measurements had an adverse effect on teaching and learning in South Africa (RSA, 2020b).

The Department of Basic Education announced a recovery plan for Basic Education on 30 April 2020, which included additional emergency funding (RSA, 2020b). This comprehensive plan consists of the following student support interventions:

- focus on achievable catch-up programmes;

- double the efforts towards the promotion of learning and teaching at home;

- prepare a catch-up programme when the children would return to school;

- use the available 123 radio stations and six television channels with a total reach of more than 35 million people. This was implemented as an intervention to bring curriculum lessons to households across the country in order to assist students as the schools remain closed;

- make available resources online for those who could access them;

- involve telecommunication partners in making academic sites zero-rated platforms; and 
- move the final and mid-year examinations for exit-level students to later in the year.

Higher Education focused their efforts on online teaching (RSA, 2020c). This implied the following two major challenges, namely, to provide sufficient access to hardware such as computers and network devices and secondly, to provide data for access to online education sites of universities. Higher Education reacted speedily in this regard by putting a tender out for the supply and delivery of laptops to students. Higher Education also negotiated zerorated data sites for academic use. The Internet Service Providers' Association of South Africa (ISPA) and mobile operators announced that almost 1000 local websites were free to access.

The South African effort to address the COVID-19 pandemic challenge was comprehensive. Internet access was one of the biggest challenges. Therefore, South African education planning for the future should focus on online accessibility.

\section{LESSONS LEARNT AND WAY FORWARD}

As stated at the outset, it was the objective of the article to explore the approaches that the BRICS nations implemented during the time of the pandemic with the intention to identify the effective practices that can serves as valuable lessons for the future. The influence of COVID-19 as an external factor on the education systems in BRICS was evident. The text clearly shows that the pandemic had a significant impact and posed many challenges on the education sector. BRICS countries updated their policies, provided funds to address emerging challenges, developed new programmes and adjusted teaching strategies. All these changes show that external factors, in this case the pandemic, have a significant impact on the functioning of national education systems. In fact, COVID-19 affected decision making and actions in terms of education provisioning and structure.

As evident in the findings, the need to provide all students, irrespective of economic status, gender or location, with quality education was taken into consideration by the governments. The respective Ministries of Education in the BRICS countries took the lead in implementing safety measures and dedicating the necessary funding to enable the required changes to ensure effective participation of all education groups. Collaboration with other social platforms such as radio and television were also at work.

More specifically, to address the challenges posed by the pandemic, BRICS nations implemented similar practices, namely closure of education institutions with their gradual selected opening; moving mainly to online teaching, new planning regarding school times and new dates for examinations. In addition, different measures were implemented to ensure successful distance education. This includes provisioning of online programmes, learning materials and teacher presentations, provisioning of the required hardware and software and the accessibility to the internet. A number of lessons can be identified based on these approaches.

The key lesson that can be derived from the findings is that education systems should be better prepared for the states of emergency such as the COVID-19 pandemic. The strategic plans should be available in advance to allow for faster adjustment to emergencies. This includes preparation to move effectively to online teaching, supervising and supporting students. Stemming from that is the next lessons related to professional development. Significant consideration should be devoted to training of educators in developing the necessary knowledge and skills to effectively engage in quality online teaching. In addition, 
support staff should also be trained how to provide a supportive learning environment. This connects to the following lesson, namely, to maximise the use of technology. Available technology should be used to the maximum advantage for all educational activities, including teaching, researching, assessing, supervising and engagement with remote communities. To that end, various e-platforms should be explored and introduced to educators, administrators and students in crisis-free times. Proficiency with digital technologies and maximised access to internet is instrumental in solving the challenges posed by the pandemic and any potential future emergencies. Another lesson that deserves attention is the power of collaboration. Although the responsibility to safeguard and support education lies with the government and the relevant Ministries of Education, inclusion of other education stakeholders (educators, administrators, students, parents) and beyond (radio, TV, other social media) is essential. Making informed decisions and actions highly depends on bringing diverse perspectives that expand the potential of effective solutions. In addition, research about creative education strategies to approach future states of emergency should be promoted. This pandemic will not last forever, however, we have to learn from it to be prepared for future emergency situations. To that end, we need to reflect about all challenges presented by the pandemic, analyse the effectiveness of the implemented interventions, consider the consequences, develop strategic plans and sustainable solutions. A crisis cannot be dealt with using standard accepted measures and practices. We need to be reminded that extraordinary circumstances call for extraordinary actions.

It is fair to conclude that now more than ever the ability to deal with unprecedented challenges calls for solidarity and information sharing. In recognition of disparities across the nations, it is our stand that every country should have the opportunity to learn from other nations about effective education approaches in crisis situations. To that end, we need to promote greater exchange of information, ideas and expertise about teaching, researching and other education activities.

\section{REFERENCES}

Berti, L. 2020. Eight Brazilian states set a date for school reopening. The Brazilian Report. Available at https://brazilian.report/coronavirus-brazil-live-blog/ [Accessed 6 October 2020].

CNN. 2020. China goes into emergency mode as number of confirmed Wuhan coronavirus cases reaches 2,700. Available at https://www.cnn.com/2020/01/26/asia/wuhan-coronavirusupdate-intl-hnk/index.html [Accessed 5 July 2020].

De Beer, Z.L. 2017. Die BRICS-organisasie: betekenis vir onderwysvoorsiening in die lidlande. PhD Thesis. Potchefstroom: North-West University.

Fox, D. 2020. What you need to know about the Wuhan coronavirus? Nature. doi:10.1038/ d41586-020-00209-y.

Foy, H. \& Seddon, M. 2020. Putin leaves tough coronavirus decisions to regional aides. Financial Times. Available at https://www.ft.com/content/05fbbf49-913d-48ec-acdc1f47c774317a [Accessed 8 October 2020].

Gettleman, J. \& Schultz, K. 2020. Modi orders 3-week total lockdown for all 1.3 billion Indians. The New York Times. Available at https://www.nytimes.com/2020/03/24/world/asia/indiacoronavirus-lockdown.html [Accessed 08 October 2020]. 
Government of India. 2020a. Ministry of Health and Family welfare: Covid-19. Available at https://www.mohfw.gov.in/ [Accessed 30 September 2020].

Government of India. 2020b. Ministry of Home Affairs, Circulars15 for Covid-19. Guidelines 24 March. Available at https://www.mha.gov.in/notifications/circulars-covid-19 [Accessed 6 August 2020].

Khakpour, A. 2012. Methodology of comparative studies in education. Contemporary Educational Researches Journal, 1: 20-26.

Ministry of Human Resource Development (MHRD). 2020. Notice: COVID-19 Stay safe: Digital initiatives. Available at https://www.mohfw.gov.in/pdf/Covid19.pdf [Accessed 25 May 2020].

Ministry of Education. 2020a. Coronavirus: know what measures the MEC has already taken or are in progress. Available at http://portal.mec.gov.br/index.php?option=com_ content\&view=article\&id=86791 [Accessed 5 August 2020].

Ministry of Education. 2020b. Methods and recommendations. Available at https://docs.edu. gov.ru/document/id/1792 [Accessed 6 August 2020].

Ministry of Education. 2020c. National education project. Available at https://edu.gov.ru/ national-project/ [Accessed 7 August 2020].

Ministry of Education. 2020d. Bank of documents. Available at https://docs.edu.gov.ru/ [Accessed 8 August 2020].

Ministry of Science and Higher Education of the Russian Federation. 2020. Valery Falkov told how the new school year will be held. Available at https://www.minobrnauki.gov.ru/ru/presscenter/card/?id_4=3020 [Accessed 9 August 2020].

Organisation for Economic Co-operation and Development (OECD). 2020. The impact of COVID-19 on education. Education at a Glance 2020. Available at the-impact-of-covid-19-oneducation-insights-education-at-a-glance-2020.pdf [Accessed 6 September 2020].

Parreiras, C. \& Macedo, R.M. 2020. Digital inequalities and education in Brazil during the COVID-19 pandemic: A brief reflection on the challenges of remote learning. Available at https://www.digitalcultureandeducation.com/reflections-on-covid19/digital-inequalities-andeducation-in-brazil [Accessed 5 October 2020 ].

Pravat, K. 2020. Challenges and opportunities created by Covid-19 for ODL: A case study of IGNOU. International Journal for Innovative Research in Multidisciplinary Filed, 6(5): 217-222.

Reuters. 2020. Wuhan lockdown "unprecedented", shows commitment to contain virus: WHO representative in China. Available at https://www.reuters.com/article/us-china-health-whoidUSKBN1ZM1G9 [Accessed 1 October 2020].

RSA. 2020a. About alert system. South African Government. Available at www.gov.za/ covid-19/about/about-alert-system [Accessed 6 July 2020].

RSA. 2020b. Minister Angie Motshekga: Basic Education Sector recovery plans for the reopening of schools, following the Coronavirus COVID-19 lockdown adjustment of regulations. Available at https://www.gov.za/speeches/minister-angie-motshekga-basic-education-sectorrecovery-plans-reopening-schools-following [Accessed 9 August 2020].

RSA. 2020c. Minister Blade Nzimande: Higher Education and Training response to Coronavirus Covid-19 epidemic lockdown level 1. Available at https://www.gov.za/speeches/ 
education-sector-response-covid-19-epidemic-lockdown-30-sep-2020-0000 [Accessed 5 September 2020].

SAcoronavirus. 2020. COVID-19 Corona Virus South African resource portal. Available at https://sacoronavirus.co.za/ [Accessed 3 October 2020].

Steyn, H.J. \& Wolhuter, C.C. 2014. The education system: A comparative education perspective. Potchefstroom: Keurkopié.

Steyn, H.J., Wolhuter, C.C., Vos, D. \& De Beer, Z.L. 2017. South African education system: Core characteristics in focus. Potchefstroom: Keurkopié.

Straitstimes. 2020. China-shuts-down-city-of-wenzhou-far-from-virus-epicenter. Available at https://www.straitstimes.com/asia/east-asia/china-shuts-down-city-of-wenzhou-far-fromvirus-epicenter [Accessed 6 August 2020].

The Moscow Times. 2020. Moscow announces two-week school break to contain Coronavirus. Available at https://www.themoscowtimes.com/2020/09/29/moscow-announces-two-weekschool-break-to-contain-coronavirus-a71581 [Accessed 10 October 2020 ].

The World Bank. 2020a. The impact of COVID-19 on education in Brazil. Available at https:// www.worldbank.org/en/events/2020/04/29/the-impact-of-covid-19-on-education-in-brazil [Accessed 1 October 2020 ].

The World Bank. 2020b. COVID-19 (Coronavirus) policy response to addressing learning gaps and inequalities in Russia. Available at https://www.worldbank.org/en/country/russia/ brief/covid-19-response-learning-gaps-inequalities-russia [Accessed 11 October 2020 ].

United Nations (UN). 2020a. UN policy brief. Available at https://www.un.org/development/ desa/dspd/wp-content/uploads/sites/22/2020/08/sg_policy_brief_covid-19_and_education_ august_2020.pdf [Accessed 5 June 2020].

United Nations (UN). 2020b. Population. Available at https://www.un.org/en/sections/issuesdepth/population/ [Accessed 28 September 2020].

United Nations Development Programme (UNDP). 2020. COVID-19: New UNDP data dashboards reveal huge disparities among countries in ability to cope and recover. Available at https://www.undp.org/content/undp/en/home/ [Accessed 25 January 2020].

UNESCO. 2020a. UNESCO rallies international organizations, civil society and private sector partners in a broad Coalition to ensure \#LearningNeverStops. Available at https://en.unesco. org/news/unesco-rallies-international-organizations-civil-society-and-private-sector-partnersbroad [Accessed 5 October 2020].

UNESCO. 2020b. How is China ensuring learning when classes are disrupted by coronavirus? Available at https://en.unesco.org/news/how-china-ensuring-learning-when-classes-aredisrupted-coronavirus [Accessed 23 August 2020].

UNESCO. 2020c. UNESCO rallies international organizations, civil society and private sector partners in a broad Coalition to ensure \#LearningNeverStops. Available at https://en.unesco. org/news/unesco-rallies-international-organizations-civil-society-and-private-sector-partnersbroad. [Accessed 16 October 2020].

UNICEF. 2020. Education: India. Available at https://www.unicef.org/india/what-we-do/ education [Accessed 5 August 2020]. 
Ward, A. 2020. India's coronavirus lockdown and its looming crisis, explained. Available at https://www.vox.com/2020/3/24/21190868/coronavirus-india-modi-lockdown-kashmir [Accessed 15 September 2020].

World Health Organization (WHO). 2020a. Timeline of WHO's response to COVID-19. Available at https://www.who.int/news/item/29-06-2020-covidtimeline [Accessed 10 October 2020].

World Health Organization (WHO). 2020b. Common questions. Available at https://www.euro. who.int [Accessed 10 October 2020].

World Health Organization (WHO). 2020c. Service announcement. Corona disease 2019, Q\&A. Available at https://www.who.int [Accessed 10 October 2020].

World Health Organization (WHO). 2020d. Key messages and actions for COVID-19 prevention and control in schools, March 2020. Available at https://www.who.int/docs/defaultsource/coronaviruse/key-messages-and-actions-for-covid-19-prevention-and-control-inschools-march-2020.pdf?sfvrsn=baf81d52_4 [Accessed 11 October 2020].

Worldometers. 2020a. Worldometers: India. Available at https://www.worldometers.info/ coronavirus/country/india/ [Accessed 30 September 2020].

Worldometers. 2020b. Worldometer: China. Available at https://www.worldometers.info/ coronavirus/country/china/ [Accessed 19 September 2020].

Worldometer. 2020c. Countries in the world by population 2020. Available at https://www. worldometers.info/world-population/population-by-country/ [Accessed 13 September 2020].

Wyman, O. 2020. Segment opportunities within China's education industry amid COVID-19 outbreak. Available at www.oliverwyman.com/dam/publication/march.html [Accessed 5 October 2020]. 